\title{
Prevalence and associated risk factors of self-medication among patients attending El-Mahsama family practice center, Ismailia, Egypt
}

Wael Zeid, Madeha Hamed, Nadia Mansour and Rokaya Diabº

\begin{abstract}
Background: Self-medication is defined as taking medications without the physician's prescription. It is a worldwide public health problem, especially in countries with limited resources. Although self-medication can reduce waiting time and save money, it may carry some potential risks, e.g., antibiotic resistance or inappropriate management with subsequent complication. A limited number of self-medication studies have been conducted in Egypt.

Objectives: To determine the prevalence of self-medication practices and to identify the factors associated with self-medication

Methods: A cross-sectional study was conducted on 160 patients. The sample was randomly selected from those who attended the El-Mahsama family practice center, Ismailia, Egypt, from November 2018 to February 2019. The center is affiliated to the Suez Canal University and provides preventive and curative services to a rural community. The participants were interviewed using a semi-structured questionnaire including sociodemographic scale and selfmedication knowledge and behavior. Data was analyzed using descriptive and analytic statistical methods.

Results: Frequency of self-medication among the study sample has reached $96 \%$. More than half of the participants (53.6\%) reported that the first reason behind using self-medication was cost saving. Meanwhile, the most prevalent conditions that make them use these medications by themselves were headaches (17\%), aches and pain (other than headache) (39.2\%), and fevers (11.8\%). The most frequent self-administered drugs were analgesics (59.5\%) and antibiotics (23.5\%).
\end{abstract}

Conclusion: Prevalence of self-medication is high among all socioeconomic levels of patients attending the ElMahsama family practice center, which serves a rural community in Ismailia governorate, Egypt.

Keywords: Self-medication, Over the counter, Self-care, Self-management, Prescription-only medicines

\section{Introduction}

Self-medication is defined as the use of medicines to treat self-diagnosed disorders without any medical consultation (Sarahroodi et al. 2012). It may involve over-thecounter (OTC) medications, prescription-only medicines $(\mathrm{POM})$, or the use of complementary and alternative

\footnotetext{
*Correspondence: Rokayamansour12@gmail.com

Department of Family Medicine, Suez Canal University, Kilo 4.5 Round Road, Ismailia 41522, Egypt
}

\section{Springer Open}

medicine (Torres et al. 2019). Methods of self-medication may include buying drugs by reutilizing a previous prescription, taking medicines on advice of relative or others, or consuming leftover medicines already available at home (Helal and Abou-ElWafa 2017). Self-medication is a global phenomenon and potential contributor to human pathogen resistance to antibiotics (Bennadi 2013). However, its patterns vary between countries depending on various features, e.g., socioeconomic factors, medical knowledge, (c) The Author(s). 2020 Open Access This article is licensed under a Creative Commons Attribution 4.0 International License, which permits use, sharing, adaptation, distribution and reproduction in any medium or format, as long as you give appropriate credit to the original author(s) and the source, provide a link to the Creative Commons licence, and indicate if changes were made. The images or other third party material in this article are included in the article's Creative Commons licence, unless indicated otherwise in a credit line to the material. If material is not included in the article's Creative Commons licence and your intended use is not permitted by statutory regulation or exceeds the permitted use, you will need to obtain permission directly from the copyright holder. To view a copy of this licence, visit http://creativecommons.org/licenses/by/4.0/. 
satisfaction and people's perception of disease, ready access to drugs, the increased potential to manage certain illnesses through self-care, and greater availability of medicinal products (Abay and Amelo 2010; Klemenc-Ketiš et al. 2011).

Although self-medication can reduce the load on medical services and save cost, it is far from being a completely safe practice (WHO 2005). Potential risks may include incorrect self-diagnosis, delays in seeking medical advice when needed, severe adverse reactions, dangerous drug interactions especially for older people with multi-morbidity, incorrect manner of administration, incorrect dosage, incorrect choice of therapy, masking of a severe disease, and development of microbial resistance (Ruiz 2010).

Antibiotics resistance, one of the biggest threats to global health, may result from self-medication of antibiotics (Rather et al. 2017). The acceleration of antibiotic resistance and the decline in the development of new antibiotics to combat the problem have created significant public health challenges to health policymakers, health care workers, and the population around the world (Gebeyehu et al. 2015). In many developing countries including Egypt, antibiotics are unregulated and available over the counter without a prescription (Ventola 2015).

Despite the potential risks of self-medication, and to the best of our knowledge, few epidemiological data is available about the prevalence of self-medication among patients in our community.

\section{Methods}

A cross-sectional study was conducted on 160 participants, who were selected by simple random sample from the daily registry of patients who attended the ElMahsama family practice center, Ismailia, Egypt, from November 2018 to February 2019. The sample size was determined by using the equation of one proportion: $n=\left[\frac{Z_{\propto / 2}}{\mathrm{E}}\right]^{2} * \mathrm{P}(1-\mathrm{P})$, where $n=$ sample size, $Z_{\alpha / 2}$ $=1.96$ (the critical value that divides the central $95 \%$ of the $Z$ distribution from the $5 \%$ in the tail), $P=88.2 \%$ (the prevalence of the outcome variable) (Kasim and Hassan 2018), and $E=0.05$, the margin of error (width of confidence interval) (Charan and Biswas 2013). The El-Mahsama family practice center was selected as a study setting, because it is a primary health care center providing preventive and curative services to a rural community with different socioeconomic levels and different cultural backgrounds. Both genders above 18 years, who live in El-Mahsama village, were included, while medical staff and drug addicts were excluded from the study. Participants were interviewed using a semistructured questionnaire, which contains two sections:
(1) socioeconomic status and (2) self-medication assessment. The socioeconomic status section contained 7 domains, with a total score of 84: education and cultural domain (score $=30$ : highest level of education and access to health information), occupation domain (score = 10: occupation of husband and wife), family domain (score $=10$ : residence, number of family members, number of earning family members, and education of children), family possessions (score $=12$ : refrigerator, television, washing machine, mobile/phone, radio, car, agricultural land, non-agricultural land for housing, shop or animal shed, computer, internet, another house rather than living in, animals/poultry), economic (score $=5$ : income sufficiency, governmental support, and taxes), home sanitation domain (score $=12$ : services, e.g., water/electricity/sewage, owned/rented, number of rooms, crowding index), and healthcare domains (score $=5$ : private/health insurance/free governmental/traditional healers). The total socioeconomic level was classified into very low, low, middle, and high levels depending on the quartiles of the score calculated (El-Gilany et al. 2012). The self-medication assessment section covers the following items in the last 12 months (Ilhan et al. 2009): frequency of self-use of medications, diseases for which medicines were self-prescribed, drugs commonly used, sources of information, reason for not consulting a doctor, and patients' opinion about selfmedication practice. Pilot testing of tools was carried out on 20 persons out of the study sample to assess the understandability and feasibility of the questionnaire. A Cronbach's alpha of 0.66 with a moderate agreement (kappa = $0.76)$ and strong positive significant correlation $(r=0.93)$ between the socioeconomic levels and scores of both scales indicated the acceptable reliability and validity of the tool of study (El-Gilany et al. 2012). The validity of the self-medication assessment tool was pre-determined by three experienced professors of family and community medicine.

\section{Data management}

Data was analyzed using the Statistical Package for the Social Sciences (SPSS), version 22 (IBM Corp., Chicago, IL, USA). Descriptive data was presented as numbers and percentages. Fisher's exact test and Pearson's chisquared test were used for statistical analysis of categorical variables. For all tests, a probability value of less than 0.05 was considered.

\section{Results}

The participants' mean age was $37.3 \pm 12.2$ years, and the majority $(89.4 \%)$ of them came from rural areas. About half of the families $(48.8 \%)$ had less than five members. Less than half of them (42.5\%) depend on free governmental health services as a usual source of health care. The skilled manual workers/farmers represent 
$23.8 \%$ among men, while about the two thirds $(63.7 \%)$ of the women were unemployed/housewives. About 57.5\% of the families have only one earning person. Regarding the crowding index, about $55 \%$ of the participants had more than one person in each room. Families who can just meet their routine expenses represent $44.4 \%$ of the overall families. The majority (80.6\%) of the participants' families receive governmental support. Regarding the level of socioeconomic status (SES), $56 \%$ and $42 \%$ had moderate and low levels respectively.

Figure 1 showed that $96 \%$ of the participants have used medications without any medical consultations or supervision, mainly to alleviate pain and fever. As shown in Table 1, about half of them owed that to save money; however, two thirds of them (62.7\%) perceive selfmedication as an unacceptable practice. Furthermore, information sources include recommendation by community pharmacists (23.5\%), previous doctor's prescriptions $(20.9 \%)$, or the patient's own experience (18.3\%). The most frequent self-administered drugs were analgesics (59.5\%) and antibiotics (23.5\%). Table 2 showed no statistically significant association between the socioeconomic status of the participants and usage of selfmedications $(P=0.56)$.

\section{Discussion}

The present study revealed a very high prevalence of self-medication (96\%), compared to the previously reported prevalence in other Egyptian studies. A recent systematic review included some Egyptian studies conducted in different cities from 1995 to 2014 (Kasim and Hassan 2018). The review demonstrated that the prevalence of medication abuse among the Egyptian population before twenty-first century ranged from 21.1 to

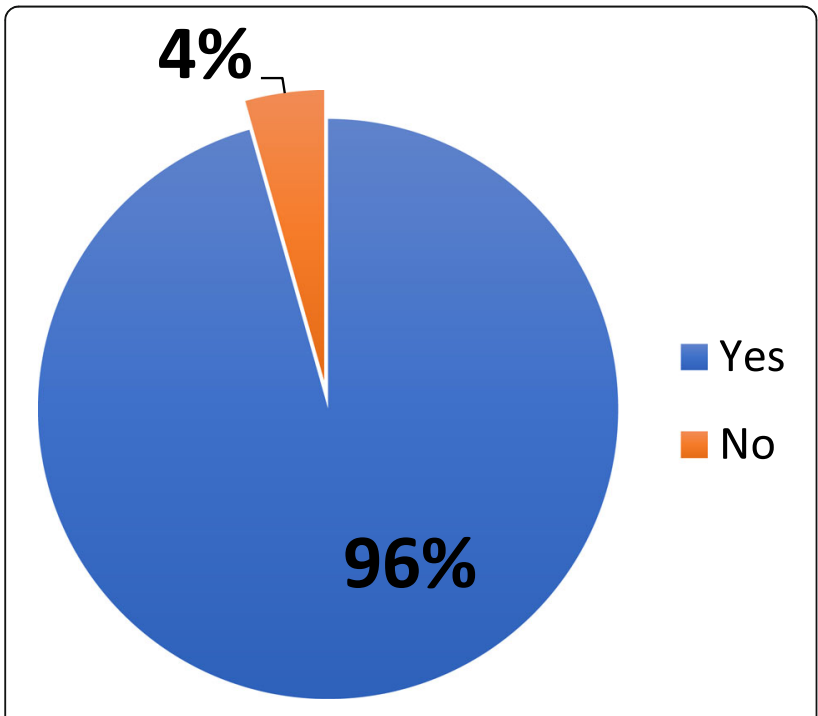

Fig. 1 Frequency of self-medication in the study sample $(N=160)$
Table 1 Items related to self-medication in the study sample $(n=153)$

\begin{tabular}{ll}
\hline Variables & $n(\%)$ \\
\hline Reasons for self-medication & \\
Cost saving & $82(53.6)$ \\
Convenience & $68(44.4)$ \\
Lack of trust in doctor & $3(2)$
\end{tabular}

Symptoms/conditions that warranted use of self-medication

$\begin{array}{ll}\text { Aches and pains } & 60(39.2) \\ \text { Headache } & 26(17) \\ \text { Fever } & 18(11.8) \\ \text { Sore throat } & 14(9.2) \\ \text { A runny nose } & 13(8.5) \\ \text { Cough } & 6(3.9) \\ \text { Nasal congestion } & 5(3.3) \\ \text { Vomiting } & 1(0.7) \\ \text { Diarrhea } & 1(0.7) \\ \text { Skin wounds } & 1(0.7) \\ \text { Others* } & 8(5.2) \\ \text { Information source } & \\ \text { Recommendation by community pharmacists } & 36(23.5) \\ \text { Previous doctor's prescription } & 32(20.9) \\ \text { Own experience } & 28(18.3) \\ \text { Opinion of family members } & 20(13.1) \\ \text { Opinion of friends } & 21(13.7) \\ \text { Recommendation by net citizens } & 16(10.5)\end{array}$

Patient opinion about self-medication on self-health care

$\begin{array}{ll}\text { Good practice } & 13(8.5) \\ \text { Acceptable practice } & 44(28.8) \\ \text { Not acceptable practice } & 96(62.7)\end{array}$

Drugs involved in self-medication

$\begin{array}{ll}\text { Analgesics } & 91(59.2) \\ \text { Antibiotics } & 36(23.5) \\ \text { Anti-histamines } & 11(7.2) \\ \text { Weight gain and weight reducing agents } & 11(7.2) \\ \text { Multivitamins } & 4(2.6)\end{array}$

*Others include dizziness, epigastric pain, low back pain, and dysuria)

Table 2 Association between socioeconomic level and using of self-medication in the study sample $(n=160)$

\begin{tabular}{lllll}
\hline Variables & \multicolumn{2}{l}{ Socioeconomic level } & $P$ value \\
\cline { 2 - 4 } & Very low $(n=4)$ & Low $(n=67)$ & Middle $(n=89)$ & \\
\hline \multicolumn{2}{l}{ Using self-medication, $\boldsymbol{n}(\%)$} & & \\
Yes & $4(100)$ & $66(98.5)$ & $83(93.3)$ & $0.56^{\text {a }}$ \\
No & 0 & $1(1.5)$ & $6(6.7)$ & \\
\hline
\end{tabular}

${ }^{\mathrm{a}} P$ values are based on Fisher's exact test. Statistical significance at $P<0.05$ 
$72 \%$. However, according to the more recent studies conducted in Egypt, the reported prevalence has significantly increased to range from 81.1 to $86.4 \%$ (Sallam et al. 2009; El-Nimr et al. 2015). As for other countries, the reported prevalence varied widely from $45.4 \%$ in China (Lei et al. 2018), 42.5\% in Jordan (Yousef et al. 2008), 53.5\% in Mexico (Balbuena et al. 2009), 65.1\% in Brazil (Bertoldi et al. 2014), 75\% in Chile (Fuentes Albarran and Villa Zapata 2008), and 79.9\% among university students in Serbia (Lukovic et al. 2014). The variations in the reported prevalence can be explained by the difference in populations, sample size, and study design. But more importantly, the recall period in these studies was only a few weeks or months, whereas in our study, self-medication use was assessed during the past whole year. This long recall period could explain the very high prevalence reported in our study.

In the present study, the most commonly used drugs were analgesics and antibiotics. This is consistent with the findings of previous studies which reported that analgesics and anti-inflammatories were highly used in self-medication (Jerez-Roig et al. 2014; Domingues et al. 2017). In fact, Domingues et al. (2017) explained this by the strong association between self-medication and the presence of minor diseases and conditions. Similarly, El-Nimr et al. (2015) reported that the most commonly used drugs were analgesics, followed by cough and common cold preparations and vitamins and minerals. They also reported that over half of the participants used antibiotics without a prescription. The same findings were reported in the systematic review by Kasim and Hassan (2018).

The socioeconomic score of the participants was not significantly associated with frequency of self-use of medications, diseases for which medicines were selfprescribed, drugs commonly used, sources of information, reason for not consulting a doctor, or patients' opinion about self-medication practice. Additionally, self-medication was not associated with participants' economic and household characteristics, in terms of their occupation, the number of earning members of the family, their income, crowding index, and whether they use governmental support. However, and contrary to our findings, Chang and Trivedi (2003) suggested that economic factors such as family size, income, and availability of health insurance may influence the selfmedication practice. Also, a large Mexican study found that those who practiced self-medication usually had lower income (Pagan et al. 2006). Meanwhile, medical insurance has been proposed as a key determinant for self-medication (Hoai and Dang 2017). Some even suggested that broadening health insurance to cover overthe-counter drugs may lead to a significant reduction in self-medication practice (Lei et al. 2018). With medical insurance come some obstacles that hinder the full utilization of such insurance and therefore direct some insured patients towards self-medication. For example, patients have to wait for quite long times to see a doctor. Also, some drugs might be unavailable sometimes, and thus, patients quite often end up buying the medications themselves. Moreover, regular, non-emergency health services are only available during usual working hours/ days, which force the employee to ask for sick leave and this may not be easily granted (Yousef et al. 2008).

\section{Limitations of the present study}

The present study had some limitations. First, the recall bias may have affected our analysis, and although the long recall period may add strength to our study, yet, it might also have caused confusion to the participants. Second, the study was a regional study conducted at a single health unit. Therefore, our results cannot be generalized and are not representing self-medication practice in Egypt. Third, since this was a cross-sectional study, each variable was measured only once and exposure and outcome are simultaneously assessed, so evidence of any associations should be closely interpreted before a causal relationship could be established.

\section{Conclusion}

Frequency of self-medication among the study sample has reached $96 \%$. There was no statistically significant association between the socioeconomic status of the participants and usage of self-medications.

\section{Acknowledgements \\ The authors would like to acknowledge all the participants for their cooperation.}

Informed consent

Informed consent was obtained from the participants included in the study.

\section{Authors' contributions}

This work was carried out in collaboration between all authors. $\mathrm{MH}$ was responsible for choosing the tool of the study. RD and WZ designed the study, wrote the manuscript, and were involved in the subject selections and data collection. NM was responsible for the statistical analysis and revised the final manuscript. All authors read and approved the final manuscript.

Funding

No fund received

\section{Availability of data and materials}

The datasets generated during this study are available from the corresponding author on reasonable request.

Ethics approval and consent to participate

All procedures performed in the study were in accordance with the ethical standards of the institutional research committee.

Consent for publication

Not applicable.

Competing interests

The authors announce that there is no conflict of interest. 
Received: 30 April 2020 Accepted: 3 June 2020

Published online: 12 June 2020

\section{References}

Abay SM, Amelo W (2010) Assessment of self-medication practices among medical, pharmacy, health science students in Gondar University. Ethiopia. Journal of Young Pharmacists. 2(3):306-310

Albarrán KF, Zapata LV (2008) Analysis and quantification of self-medication patterns of customers in community pharmacies in southern Chile. Pharmacy world \& science. 30(6):863-868

Balbuena FR, Aranda AB, Figueras A (2009) Self-medication in older urban Mexicans. Drugs \& aging. 26(1):51-60

Bennadi D (2013) Self-medication: a current challenge. Journal of basic and clinical pharmacy. 5(1):19

Bertoldi AD, Camargo AL, Silveira MP, Menezes AM, Assunção MC, Gonçalves H et al (2014) Self-medication among adolescents aged 18 years: the 1993 Pelotas (Brazil) birth cohort study. Journal of adolescent health. 55(2):175-18

Chang FR, Trivedi KP (2003) Economics of self-medication: theory and evidence. Health economics. 12(9):721-739

Charan J, Biswas T (2013 Apr) How to calculate sample size for different study designs in medical research? Indian journal of psychological medicine. 35(2):121

Domingues PH, Galvão TF, Andrade KR, Araújo PC, Silva MT, Pereira MG (2017) Prevalence and associated factors of self-medication in adults living in the Federal District, Brazil: a cross-sectional, population-based study. Epidemiologia e Serviços de Saúde. 26:319-330

El Gilany A, El-Wehady A, El-Wasify M (2012) Updating and validation of the socioeconomic status scale for health research in Egypt. Eastern Mediterranean Health Journal. 1:18(9)

El Nimr NA, Wahdan IM, Wahdan AM, Kotb RE (2015) Self-medication with drugs and complementary and alternative medicines in Alexandria, Egypt: prevalence, patterns and determinants. EMHJ-Eastern Mediterranean Health Journal. 21(4):256-265

Gebeyehu E, Bantie L, Azage M (2015) Inappropriate use of antibiotics and its associated factors among urban and rural communities of Bahir Dar City Administration, Northwest Ethiopia. PloS one 10(9)

Helal RM, Abou-EIWafa HS (2017) Self-medication in university students from the city of Mansoura, Egypt. Journal of environmental and public health. 2017

Hoai NT, Dang T (2017) The determinants of self-medication: evidence from urban Vietnam. Social work in health care. 56(4):260-282

Ilhan MN, Durukan E, Ihan SÖ, Aksakal FN, Özkan S, Bumin MA (2009) Selfmedication with antibiotics: questionnaire survey among primary care center attendants. Pharmacoepidemiol Drug Saf. 18(12):1150-1157. https://doi.org/ 10.1002/pds. 1829

Jerez-Roig J, Medeiros LF, Silva VA, Bezerra CL, Cavalcante LA, Piuvezam G et al (2014) Prevalence of self-medication and associated factors in an elderly population: a systematic review. Drugs \& aging 31(12):883-896

Kasim K, Hassan H (2018) Self-medication problem in Egypt: a review of current and future perspective. Int J Cur Res Rev. 10(4):40-45

Klemenc-Ketiš Z, Hladnik Ž, Kersnik J (2011) A cross sectional study of sex differences in self-medication practices among university students in Slovenia. Collegium antropologicum. 35(2):329-334

Lei X, Jiang H, Liu C, Ferrier A, Mugavin J (2018) Self-medication practice and associated factors among residents in Wuhan, China. International journal of environmental research and public health 15(1):68

Lukovic JA, Miletic V, Pekmezovic T, Trajkovic G, Ratkovic N, Aleksic D, Grgurevic A (2014) Self-medication practices and risk factors for self-medication among medical students in Belgrade, Serbia. PloS one 9(12)

Pagan JA, Ross S, Yau J, Polsky D (2006) Self-medication and health insurance coverage in Mexico. Health policy. 75(2):170-177

Rather IA, Kim BC, Bajpai VK, Park YH (2017) Self-medication and antibiotic resistance: crisis, current challenges, and prevention. Saudi journal of biological sciences. 24(4):808-812

Ruiz ME (2010) Risks of self-medication practices. Current drug safety. 5(4):315-323

Sallam SA, Khallafallah NM, Ibrahim NK, Okasha AO. Pharmacoepidemiological study of self-medication in adults attending pharmacies in Alexandria, Egypt. EMHJ-Eastern Mediterranean Health Journal, 15 (3), 683-691, 2009. 2009.

Sarahroodi S, Maleki-Jamshid A, Sawalha AF, Mikaili P, Safaeian L (2012) Pattern of self-medication with analgesics among Iranian University students in central Iran. Journal of family \& community medicine. 19(2):125
Torres NF, Chibi B, Middleton LE, Solomon VP, Mashamba-Thompson TP (2019) Evidence of factors influencing self-medication with antibiotics in low and middleincome countries: a systematic scoping review. Public health. 168:92-101

Ventola CL (2015) The antibiotic resistance crisis: part 1: causes and threats. Pharmacy and therapeutics. 40(4):277

World Health Organization. Guidelines for the regulatory assessment of medicinal products for use in self-medication. Geneva: World Health Organization; 2005. https://apps.who.int/iris/bitstream/handle/10665/66154/WHO_EDM_ QSM_00.1_eng.pdf (Accessed 10 December 2018).

Yousef AM, Al-Bakri AG, Bustanji Y, Wazaify M (2008) Self-medication patterns in Amman. Jordan. Pharmacy World \& Science. 30(1):24-30

\section{Publisher's Note}

Springer Nature remains neutral with regard to jurisdictional claims in published maps and institutional affiliations.

\section{Submit your manuscript to a SpringerOpen ${ }^{\circ}$ journal and benefit from:}

- Convenient online submission

- Rigorous peer review

- Open access: articles freely available online

- High visibility within the field

- Retaining the copyright to your article

Submit your next manuscript at $\boldsymbol{\nabla}$ springeropen.com 